\title{
EFFECT OF TYPE OF REINFORCEMENT ON CLINICAL DENTURE BASE DEFORMATION WITH TELESCOPIC ATTACHMENTS OF IMPLANT RETAINED OVERDENTURES. A WITHIN SUBJECT CLINICAL STUDY
}

\author{
Dina Bahgat El Talawy* and May Mahmoud Hassan**
}

\begin{abstract}
Aim: The aim of this within-subject study was to evaluate and compare clinical denture base deformation with two types of denture base reinforcement for telescopic implant retained overdentures.

Materials and methods: Six completely edentulous participants received two implants in the canine region of the mandible and the implants were connected to the overdentures with resilient telescopic attachments. Each patient received 2 types of denture reinforcement for the mandibular overdentures; 1) metal reinforced overdentures, 2) PEEK reinforced overdentures. Four straingauges were adhered to the lingual polished surface of each denture abutment top (C1 and C3), and $5 \mathrm{~mm}$ below abutment top (C2 and $\mathrm{C} 4)$. Strain registrations were performed during maximum voluntary clenching.
\end{abstract}

Results: The measured strains and implant positions $\mathrm{C} 1$ and $\mathrm{C} 3$ were tensile in nature and the measured strains at implant positions $\mathrm{C} 2$ and $\mathrm{C} 4$ were compressive in nature. The highest microstrain was noted at $\mathrm{C} 3$, followed by $\mathrm{C} 1$, then $\mathrm{C} 2$, and the lowest strain was noted was with $\mathrm{C} 4$ for both groups. There was no significant difference in recorded microstrains between $\mathrm{C} 1$ and $\mathrm{C} 3$ or between $\mathrm{C} 2$ and $\mathrm{C} 4$. For all strain gauge positions, PEEK reinforced overdentures recorded significantly higher microstrains than metal-reinforced overdentures.

Conclusion: Within the limitation of this short term cross over trial, cobalt-chromium metal reinforcement for mandibular implant assisted overdentures is recommended than PEEK reinforcement as it reduced denture base strains and deformation during maximum voluntary clenching.

* Associate Professor, Removable Prosthodontic Department College of Oral and Dental Surgery, Misr University for Science and Technology,Giza Egypt.

** Lecturer, Removable Prosthodontic Department College of Oral and Dental Surgery, Misr University for Science and Technology, Giza Egypt. 


\section{INTRODUCTION}

A common problem associated with the management of edentulous patients is the resorbed ridge of the lower jaw ${ }^{1-4}$. This results in the fabrication of unsatisfactory dentures with poor retention and stability, impaired load-bearing capacity, reduced oral function due to pain during mastication, and psychosocial problems ${ }^{5-8}$. However, the stabilization of the lower denture with two inter-foraminal implants has provided reliable and predictable treatment outcomes. It is regarded as the minimum standard of care for edentulous patients ${ }^{9}$. Various types of attachments could be used to retain dentures to the implants. The most commonly used types include splinted anchors (bars), and non-splinted anchors (magnets, ${ }^{10}$ ball anchors, and rigid and resilient telescopic copings ${ }^{11}$ ). The unsplinted attachments have several advantages compared to splinted attachments such as ease of performing oral hygiene and cleaning, ease of construction, the reduced cost, the possibility of use with v-shaped arches without compromising the tongue space ${ }^{12}$. An important factor in the selection of attachments for mandibular overdenture is the degree of ridge atrophy ${ }^{13}$. The attachment, in this case, should provide adequate retention and stability to minimize lateral movements of the denture. This is best achieved with the ball, bar, and parallel-walled telescopic crowns ${ }^{14}$.

Telescopic attachment is composed of a primary coping attached to the implant, and a secondary coping that is contained within the overdenture ${ }^{15}$, ${ }^{16},{ }^{17}$. It can be classified into parallel-sided (rigid) or tapered (resilient) depending on the degree of fit between the two copings ${ }^{15}$. With rigid telescopes: the retention is coming form friction between the 2 copings, while tapered telescopes exhibit friction only when completely seated and retention is determined by the degree of taper ${ }^{17}$. Nonrigid telescopes have no defined end position and include crowns with tiny spaces between the copings allowing vertical and rotational movement ${ }^{18,19}$. The telescopic attachment provides good retention by friction, excellent stability, lower complications and maintenance ${ }^{20}$, good indirect retention and self-seating mechanism that facilitates prosthesis insertion for geriatric patients ${ }^{21}$.

The overdenture is constructed from acrylic resin, therefore the denture base deformation during mastication is likely to occur due to the resiliency of oral mucosa and the contact of the denture base to the implants ${ }^{22}$. Studying the deformation of the denture base is important to prevent denture fracture in areas adjacent to the implant(s). This fracture tends to occur due to the inadequate thickness of acrylic resin around the attachments ${ }^{23-25}$. The clinical consequences of denture base deformation are denture fracture and biological problems as mucosal ulceration, ridge resorption, implant overload, peri-implant bone loss and implant loss. In a recent study, the authors recommended reinforcement of the denture base around the bar and telescopic attachments used for 2 implant mandibular overdentures to prevent the possible denture base deformation and fracture ${ }^{26}$.

Although metal frameworks reduced the functional deformation and problems of the supporting tissue $^{27}$, they are heavier, require complicated fabrication steps and in some patients possibility of hypersensitivity may exsists ${ }^{28}$. Other materials can be used to decrease deformation and avoid bad appearance and reduced adhesion of metal to acrylic resin of the dentures ${ }^{29}$ such as carbon fibrils, fiber glasses, or rigid polyethylene fiber. However, these materials are time consuming and less accurate than CAD/CAM technologies ${ }^{30}$. Recently, Polyetherether-ketone (PEEK) is used as a metallic frame for fixed and removable prosthesis. This is corrosion resistant, radiolucent, has reduced wear, biocompatible, not allergic and has reduced modulus of elasticity than metal and ceramic materials ${ }^{31}$. It also has low creep, high wear resistance and good shock absorption ${ }^{32,33}$. The material frames for pros- 
thesis can be constructed by milling and thermopressing. Reviewing the literature, the effect of the type of denture base reinforcement for mandibular 2 implant overdentures on clinical deformation of the overdenture base was not investigated. Therefore, this study aimed to evaluate effect of type of reinforcement on clinical denture base deformation with telescopic attachments of 2-implant retained overdentures.

\section{MATERIALS AND METHOD}

\section{Patient enrollment in and study design}

Six completely edentulous participants ( 3 males and 3 females, mean age $=56$ years) were selected from the patients attending the Prosthodontic Department clinic of College of Oral and Dental surgery of Misr University for Science and Technology asking for suitable alternative to their conventional mandibular dentures. The inclusion criteria are; 1) All participants complained of a lack of stability and retention of mandibular dentures due to advanced mandibular ridge resorption, 2) Adequate bone volume and density in the area between the mental foramina to receive implants of at least $3.5 \mathrm{~mm}$ in diameter and $10 \mathrm{~mm}$ in length. This was ascertained by Cone-beam computerized tomography, 3) normal maxillomandibular relationships, 4) adequate interarch distance with restorative space (at least $15 \mathrm{~mm}$ ) from the mucosa to the occlusal plane. The patient who had one of the following conditions was excluded from the study; 1) smoking habits, 2) clenching or bruxism habits, 3) neuromuscular disorders such as Parkinson's disease, 4) bone metabolic disease such as diabetes mellitus and hyperparathyroidism, 5) systemic diseases that can complicate implant placement such as bleeding disorders, heart disease, and autoimmune disease, 6) patient with radiation therapy to head and neck region. The study protocol was explained for all participants before obtaining an informed consent from each participant. The protocol was approved by the ethical committee of the faculty of dentistry (No 40). All participants received two implants in the canine region of the mandible. The implants were connected to the overdentures using resilient telescopic attachments. The study was conducted within the same participant in a cross-over design, i.e. each patient has received 2 types of denture reinforcement. The participants were categorized into two blocks ( 3 patients in each block). The first block contains 3 patients who received metal-reinforced mandibular overdentures first and wear them for 3 months, then after measurement of denture base deformation, they received PEEK-reinforced mandibular overdentures and the measurements were repeated again after 3 months of denture wearing. The second block contains 3 patients who received PEEK -reinforced mandibular overdentures first and wear them for 3 months, then after measurement of denture base deformation, they received metal-reinforced mandibular overdentures and the measurements were repeated again after 3 months of denture wearing. This randomization aimed to avoid the effect of the order of the reinforcement type on the denture strain measurements.

\section{Surgical and prosthetic interventions}

The old mandibular denture was duplicated into clear acrylic resin with radiopaque markers attached to the duplicate denture at proposed implant positions. CBCT was performed to evaluate implant sites, select the proper implant lengths and widths. The duplicate denture was then converted to surgical template after attaching metal tubes. A mid crestal incision was made from premolar area on one side to premolar area of the other side. Then a full-thickness mucosal flap was elevated. Bone recontouring was made using osteotome if needed. Two osteointegrated implants (Dentium, South Korea) were inserted in canine areas using two stage surgical protocol. The flap was closed using interrupted sutures. The denture was relieved and relined with soft liner. 
After 2 months of healing, new maxillary and mandibular conventional dentures were constructed with bilateral balanced occlusion concept using semi-anatomic acrylic teeth (CD group, control). The dentures were delivered to the patients and necessary adjustments were performed. After three months, implants were uncovered and healing abutments of appropriate gingival height were connected to the implants. Custom tray was constructed for mandibular ridge with opening over implant sites and border molded with green compound. Long transfer copings were connected to the implants and open tray impression was made. The transfer copings were splinted with Duralay resin to avoid movement during impression making. Implant analogues were connected to the implants and the impression was poured

Ti-base abutments were threaded to the analogues on the cast. The abutments were waxed on the plastic portion to make primary crowns (copings) with $6 \mathrm{~mm}$ in height and $5 \mathrm{~mm}$ in diameter. The abutments were milled using a milling device. The 2 wax patterns were milled to make their circumferential walls parallel to each other's in mesiodistal and buccolingual direction regardless of implant inclination. The wax was invested, casted into cobalt-chromium alloy ${ }^{16,34,35}$ (Heraenium Pw, Heraeus-Kulzer GmbH, Hanau, Germany), and refined by milling again and tried in the patient mouth (fig 1). Two secondary copings were designed over the primary copings with a $1.0 \mathrm{~mm}$-thickness, invested and casted with cobalt-chromium alloy. The secondary copings were placed over the primary copings on the master cast. A small circumferential and occlusal spaces were made between the inner and outer copings using a disclosing material (Fit Checker). These spaces were made by grinding the middle and occlusal surfaces of the primary crowns to make an occlusal taper to provide resiliency and torquing of the implants during mastication ${ }^{11,15}$.

The cast was scanned using CAD/CAM device (Amann Girrbach, Austria). Using the software of the device, the reinforcement frame was designed

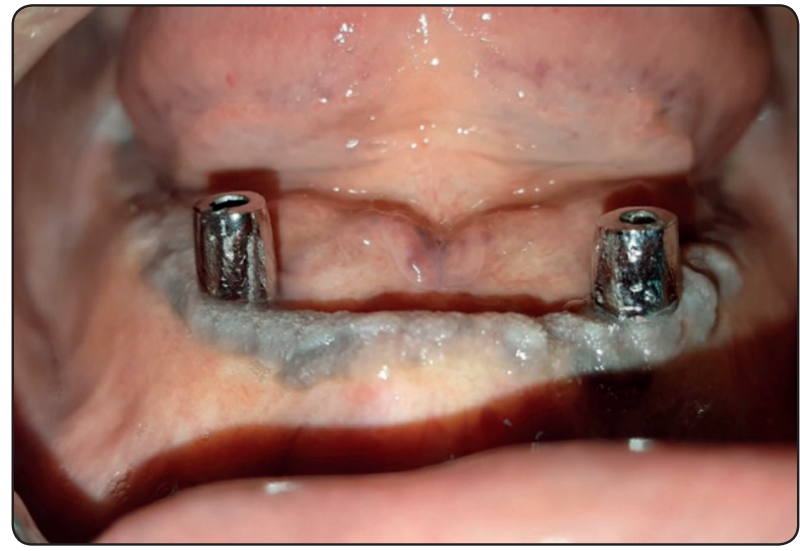

Fig. (1) Primary crowns in patients mouth

with a $1.0 \mathrm{~mm}$-thickness to cover the crest of the ridge and the attachment and saved as STL file. The designed frame was either printed in castable resin using prototyping (metal reinforced group) or milled in PEEK blocks (PEEK reinforced group). For metal reinforced group, the resin frames were invested and casted into cobalt chromium metal (fig 2a ). For PEEK reinforced group, frames were milled in modified PEEK discs (BioHPP, Bredent, Germany) (fig 2b). The thickness of both metal and PEEK frames was standardized at $1.5 \mathrm{~mm}^{30}$. Each patient received one metal reinforced overdenture and one PEEK reinforced overdenture in 2 occasions separated by 3 months time interval to enhance neuromuscular adaptation.

The polished and occlusal surfaces of mandibular denture were replicated using the rubber base mold ${ }^{24,25}$. The mold was placed over the cast. Acrylic resin teeth of the same size were replaced

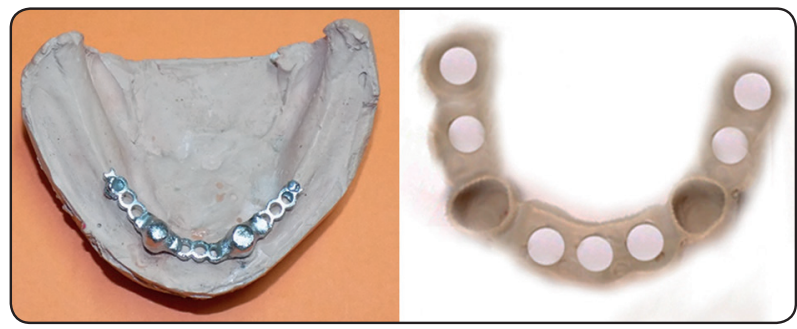

Fig. (2) a. Metal reinforcement frame, b; PEEK reinforcement frame 
in the mold and baseplate wax was poured in the mold. The dentures were processed in usual manner by the same technician. The telescopic crowns were picked up to the fitting surface of the overdentures using self cure acrylic resin while patient closes in centric occlusion to ensure optimal fit without implant overloading and to compensate for mucosal compression. By this manner, a resilient telescopic attachment was obtained (Fig 3).

\section{Measurement the denture base deformation}

The deformation of the denture base was measured by my calculation of the strain within the denture base as described by Elsyad et al. ${ }^{24-26}$ Four strain-gauges (KFG-1-120-C1-11L1M2R; KYOWA, Tokyo, Japan; resistance $119.6 \pm 0.4 \% \Omega$; gauge factor: $2.08 \pm 1.0 \%$ ) were adhered to the lingual polished surface of each denture using a special adhesive. The gauges were aligned horizontally parallel opposite to each attachment to the occlusal plane ${ }^{24}$ on the left (C1 and $\left.\mathrm{C} 2\right)$ and on the right (C3 and C4) sides (fig4). The top gauges (C1, C3) located at top of the attachments and bottom gauges $(\mathrm{C} 2, \mathrm{C} 4)$ located $5 \mathrm{~mm}$ lower to that of top gauges ${ }^{24,36}$.

The fine lead wires were brought through the interproximal acrylic resin between artificial teeth. The wires were adhered to the labial polished surface with a special resin to avoid accidental movement during biting and emerged from patient mouth at midline. The gauges were isolated from saliva with a Chloroprene rubber (HAMATITE-Y., KYOWA). The end of the lead wires were connected to a digital strainmeter (Tinsely, UK) in a half Wheatstone bridge to reduce the effect of temperature (each active gauge was connected to an identical dummy gauge). Strain registrations were performed during maximum voluntary clenching (fig. 5) with 5-seconds relaxation periods. Each clenching repeated five times for each attachment and the mean was subjected to statistical analysis.

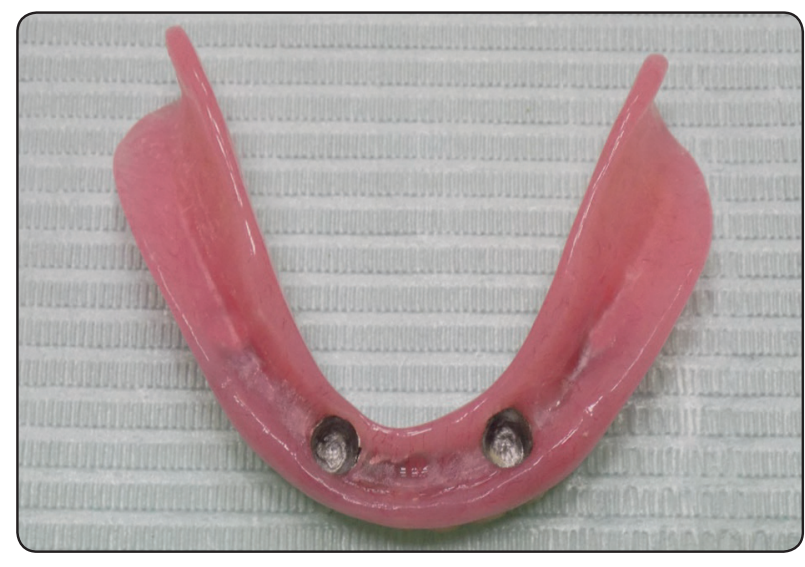

Fig. (3) Fitting surface of the dentures with secondary crowns (coping in place)

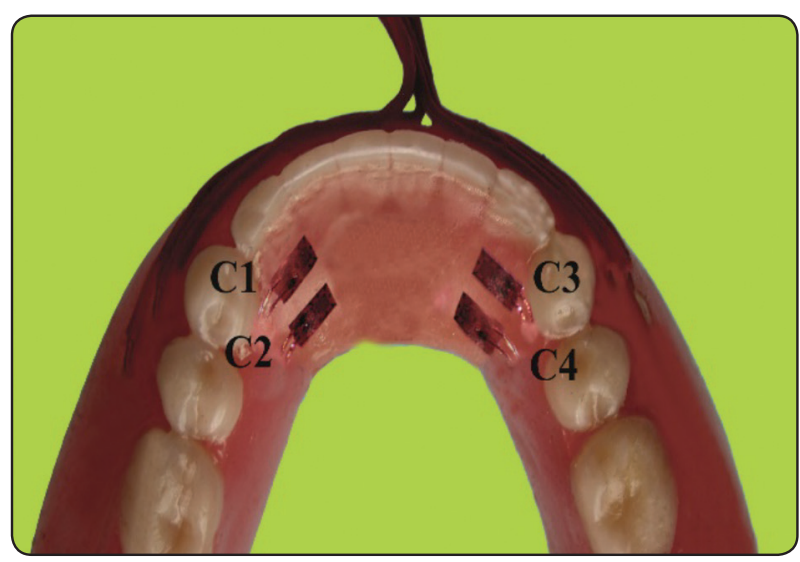

Fig. (4) Strain gauge positions on the polished surface of the dentures

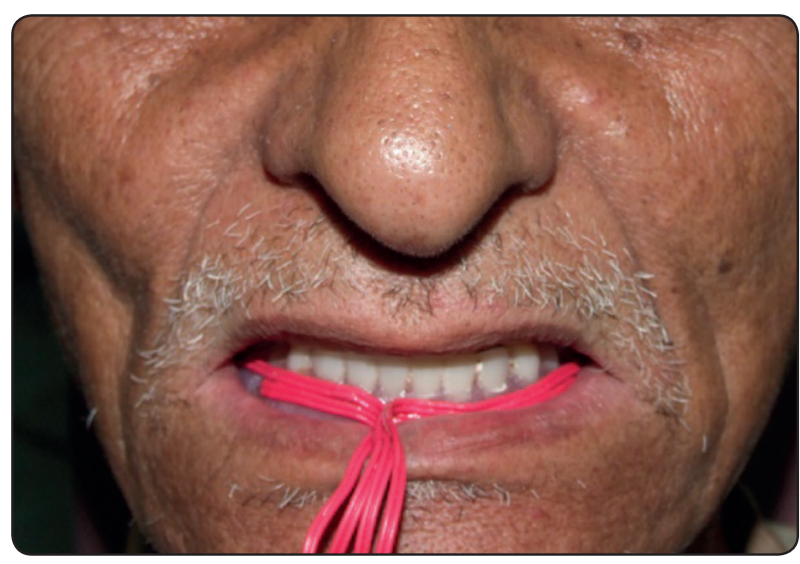

Fig. (5) Recording of denture strains during maximum voluntary clenching 


\section{Statistical analysis}

Shapiro-Wilk test was used to verify the distribution of the microstrain data. The data was parametric and presented as mean and SD for descriptive statistics. Independent samples t-test was used to compare microstrains between groups (types of reinforcement). To compare microstrain values between strain gauge positions, One Way ANOVA was used followed by Bonferroni method for pair-wise comparisons (post hoc test). The statistical analysis was performed with a computer software (SPSS V. 25, Chicago, IL, USA). A P-value $<0.05$ was considered to be statistically significant.

\section{RESULTS}

The participants attended the follow-up sessions without dropouts. No implant failures occurred and the survival rate was $100 \%$. The measured microstrains that had a positive sign indicate tensile strains within the denture base, while the negative sign of microstrains indicate compressive strains. The measured strains and implant positions $\mathrm{C} 1$ and $\mathrm{C} 3$ were tensile in nature and the measured strains at implant positions $\mathrm{C} 2$ and $\mathrm{C} 4$ were compressive in nature (table 1). The absolute value of microstrains indicated the magnitude of strains regardless of the sign. The descriptive statistics of recorded microstrains were presented as mean \pm standard deviation.

Comparison of denture base microstrains between groups (denture reinforcement) and between strain gauge locations is presented in table 1. For each group, there was a significant difference in absolute microstrains between strain gauge positions $(p=.001$ four metal reinforced overdentures and $\mathrm{p}<.001$ for PEEK reinforced Overdentures). The highest microstrain was noted that $\mathrm{C} 3$, followed by $\mathrm{C} 1$, then $\mathrm{C} 2$, and the lowest strain was noted was with $\mathrm{C} 4$ for both groups. Multiple comparisons between strain gauge positions are presented in table 2 . The p-value in each cell in table 2 presented the results of the Bonnferoni test for pairwise comparisons after correction of the $\mathrm{p}$-value for multiple testing. $\mathrm{C} 1$ and $\mathrm{C} 3$ showed significantly higher microstrains than $\mathrm{C} 2$ and $\mathrm{C} 4$. There was no significant difference in recorded microstrains between $\mathrm{C} 1$ and $\mathrm{C} 3$ or between $\mathrm{C} 2$ and $\mathrm{C} 4$.

Comparison of denture base absolute microstrains between groups (denture reinforcement) is presented in table 1. For all strain gauge positions, PEEK reinforced Overdentures recorded significantly higher microstrains than metal-reinforced overdentures ( $\mathrm{p}=.002, .023, .004$, and .039 for $\mathrm{C} 1$, $\mathrm{C} 2, \mathrm{C} 3$, and $\mathrm{C} 4$ respectively).

TABLE (1) Comparison of denture base microstrains between groups (denture reinforcement) and between strain gauge locations

\begin{tabular}{|c|c|c|c|c|c|}
\hline & C 1 & $\mathrm{C} 2$ & C 3 & C 4 & $\begin{array}{l}\text { One Way } \\
\text { ANOVA } \\
\text { (p value) }\end{array}$ \\
\hline $\begin{array}{c}\text { Metal } \\
\text { reinforced } \\
\text { Overdentures } \\
\mathrm{X} \pm \mathrm{SD}\end{array}$ & $\begin{array}{c}150 \pm \\
25.14\end{array}$ & $\begin{array}{l}-87 \pm \\
28.9\end{array}$ & $\begin{array}{r}160 \pm \\
35.58\end{array}$ & $\begin{array}{r}-78 \pm \\
17.8\end{array}$ & $.001 *$ \\
\hline $\begin{array}{c}\text { PEEK } \\
\text { reinforced } \\
\text { Overdentures } \\
\mathrm{X} \pm \mathrm{SD}\end{array}$ & $\begin{array}{l}210 \pm \\
38.17\end{array}$ & $\begin{array}{c}-102 \pm \\
15.5\end{array}$ & $\begin{array}{l}225 \pm \\
40.37\end{array}$ & $\begin{array}{l}-99 \pm \\
20.7\end{array}$ & $<.001 *$ \\
\hline $\begin{array}{l}\text { Independent } \\
\text { samples t-test } \\
\text { (p value) }\end{array}$ & $.002 *$ & $.023 *$ & $.004 *$ & $.039 *$ & \\
\hline
\end{tabular}


TABLE (2) Multiple comparison of microstrains between strain gauge locations for both groups

\begin{tabular}{|c|c|c|}
\hline Group & $\begin{array}{c}\text { Strain gauge } \\
\text { Location }\end{array}$ & $\begin{array}{c}\text { Bonferroni test } \\
\quad \text { (p value) }\end{array}$ \\
\hline \multirow{6}{*}{$\begin{array}{l}\text { Metal } \\
\text { reinforced } \\
\text { Overdentures }\end{array}$} & C1_C2 & $.001 *$ \\
\hline & C1_C3 & .145 \\
\hline & C1_C4 & $.002 *$ \\
\hline & C2_C3 & $<.001 *$ \\
\hline & C2_C4 & .087 \\
\hline & C3_C4 & $<.001$ \\
\hline \multirow{6}{*}{$\begin{array}{l}\text { PEEK } \\
\text { reinforced } \\
\text { Overdentures }\end{array}$} & C1_C2 & $.002 *$ \\
\hline & C1_C3 & .356 \\
\hline & C1_C4 & $.004 *$ \\
\hline & C2_C3 & $<.001 *$ \\
\hline & C2_C4 & .179 \\
\hline & C3_C4 & $.005^{*}$ \\
\hline
\end{tabular}

\section{DISCUSSION}

Although denture strains were evaluated in several invitro studies, the experimental setup for these studies will not replicate the clinical circumstances in the oral cavity such as the presence of saliva, the thickness and compressibility of the soft tissues. Also the application of force is usually performed using universal testing machine at a constant load which are differ from the power and direction of occlusal force of the masticatory muscles of the patient ${ }^{37}$. Thus the most precise evaluation denture strains and deformation of overdentures, should be made clinically in patient mouth (in vivo) ${ }^{38}$.

This within subject study allow the same patient to receive different types of overdentures. In this manner several factors that may affect the denture base deformation such as gender, strength of the muscles, mucosal thickness, degree of ridge atrophy and level of neuromuscular adaptation are standardized for both types of the overdentures.
Moreover, the occlusion and polished surface of the overdentures were replicated. This was performed to standardize shape, denture base thickness, form of the teeth quantities as these factors may affect the pattern of denture base deformation ${ }^{26,39-41}$. In this study the reinforcement frame was extended above the abutments and applied to the basal surface side of the denture base ${ }^{36}$. Moreover, two distal extensions of each frame was extended posteriorly on the alveolar ridge to improve the rigidity of the denture base based on the recommendation of another in vitro study ${ }^{36}$.

The limitations of using strain gauge in the oral cavity including the temperature of the oral cavity and isolation of the gauges from saliva ${ }^{42}$. However these limitations are overcome by using dummy gauges (acrylic samples) in $1 / 2$ circuit Wheatstone bridge to compensate for thermal changes. Moreover the gauges were isolated from saliva by Chloroprene rubber provided by the manufacture. Four strain gauges were attached opposite to the top of each attachment in the lingual surface of mandibular overdenture to measure strains in the denture based on the recommendation of other studies $^{24,36,43}$. These positions were selected because deformation of assisted implant overdentures usually occurs in the anterior portion of the overdentures due to inadequate thickness of acrylic around the attachments ${ }^{44,45}$.

During maximum voluntary clenching, the top gauges ( $\mathrm{C} 1$ and $\mathrm{C} 3)$ showed tensile strains and the lower gauges recorded compressive strains for both groups. The tensile strains tended to induce crack formation that may propagate to denture fracture at $\mathrm{C} 1$ and $\mathrm{C} 3$. On the other hand, the acrylic resin of the denture tended to be compressed $5 \mathrm{~mm}$ below the level of the top of the attachments. The increased tensile strains at $\mathrm{C} 1$ and $\mathrm{C} 3$ is in line with previous in vitro ${ }^{25,36,43}$ and in vivo ${ }^{24}$ studies in which the authors reported increased tensile strain close to the top of overdenture abutments. This could be attributed to the larger dimensions of the telescopic crowns occupied in the denture base that may cause 
a decrease in the thickness of the acrylic resin at this area. Also the compressibility of the oral mucosa during maximum voluntary clenching may cause telescopic primary crowns to act as a fulcrum which may increase tensile strain at level of the top of telescopic crowns ${ }^{25}$. This means that denture reinforcement either with metal or PEEK frameworks did not totally prevent overdenture strains with telescopic retained mandibular overdentures. The absence of control group (in which the denture base is not reinforced) in this study should be acknowledged as a limitation.

On the other hand, the compressive strains at the bottom gauges are less harmful to the denture base and are associated with reduced denture base fracture ${ }^{36}$. This agreed with the results of other in vitro ${ }^{25}$ and in vivo ${ }^{24}$ studies on mandibular implant overdentures. Therefore, the effect of reinforcement is evident at the top of the attachments more than the bottom and it is recommended to reinforce the denture base to reduce denture fracture at theses areas especially with increased size of the attachments like telescopic crowns. Conversely, no reinforcement of the denture base is needed below the level of the abutments. This may be clinically important as extending the reinforcement frame near the denture peripheries may complicate the denture border adjustments especially with resorbed ridges.

For all strain gauge positions, PEEK reinforced overdentures recorded significantly higher microstrains than metal-reinforced overdentures. This could be attributed to the increased rigidity of the metal reinforcement frame compared to PEEK reinforced frame when the thickness of the frames are standardized. Similarly, in another study the authors found that the increased rigidity of the denture causes even load distribution to the implants and residual ridge ${ }^{46}$ which may contribute to reduce denture base thickness. The increased denture strains with PEEK reinforcement may be attributed to the reduced modulus of elasticity of the PEEK material, compared to Cr-Co castings ${ }^{32,33}$ which make it more flexible thus enhancing more flexion and de- formation of the acrylic resin of the denture base. The reduced denture strains with cobalt chromium reinforcement was in line with results of Takahashi et al. ${ }^{47}$ who found a reduced strain around implants supporting a palateless maxillary overdenture with metal reinforcing and a palatal bar less. They added that palatal bar may enhance the rigidity of dentures with partial palatal coverage. Smilarly, in another investigation, Hada et al. ${ }^{30}$ reported that $\mathrm{CAD} /$ CAM reinforcement metal frame is beneficial in reduction of conventional denture deformation and denture strains. They found that PEEK showed a reduced reinforcement effect than cobalt chromium. In agreement with our observation, the authors in another systematic review concluded that strains on the underlying supporting structures of overdenture prostheses including dental implants and the residual ridge can be decreased and evenly distributed using a metal reinforcement ${ }^{46}$. Similarly in another in vitro study ${ }^{36}$, the authors reported that overdentures with cast metal cobalt-chromium reinforcement were associated with significantly reduced denture strains than overdentures with no reinforcement or stainless steel wire reinforcement. Also Takahashi et al. concluded that cast reinforcement over the residual ridge and the top of copings embedded in an acrylic base reduced the strain from occlusal stress on maxillary implant overdentures. ${ }^{48}$

The limitations of this study include the small sample size, the short evaluation period and the lack of control group. Future studies are needed to evaluate the longevity of the denture base, prosthetic aspects and complications of the two types of the tested denture base reinforcement for mandibular two implant retained overdentures.

\section{CONCLUSION}

Within the limitation of this short term cross over trial, cobalt-chromium metal reinforcement for mandibular implant assisted overdentures is recommended than PEEK reinforcement as it reduce denture base strains and deformation during maximum voluntary clenching. 


\section{REFERENCES}

1. Mericske-Stern RD, Taylor TD, Belser U. Management of the edentulous patient. Clin Oral Implants Res 2000; 11 Suppl 1: 108-125.

2. Muller F, Heath MR, Ott R. Maximum bite force after the replacement of complete dentures. Gerodontology 2001; 18: 58-62.

3. Muller F, Naharro M, Carlsson GE. What are the prevalence and incidence of tooth loss in the adult and elderly population in Europe? Clin Oral Implants Res 2007; 18 Suppl 3: 2-14.

4. Carlsson GE, Omar R. The future of complete dentures in oral rehabilitation. A critical review. J Oral Rehabil 2010; 37: 143-156.

5. Allen PF, McMillan AS, Walshaw D. A patient-based assessment of implant-stabilized and conventional complete dentures. J Prosthet Dent 2001; 85: 141-147.

6. Heckmann SM, Heussinger S, Linke JJ, Graef F, Proschel P. Improvement and long-term stability of neuromuscular adaptation in implant-supported overdentures. Clin Oral Implants Res 2009; 20: 1200-1205.

7. Muller F, Hernandez M, Grutter L, Aracil-Kessler L, Weingart D, Schimmel M. Masseter muscle thickness, chewing efficiency and bite force in edentulous patients with fixed and removable implant-supported prostheses: a cross-sectional multicenter study. Clin Oral Implants Res 2012; 23: 144-150.

8. Awad MA, Lund JP, Shapiro SH, Locker D, Klemetti E, Chehade A, Savard A, Feine JS. Oral health status and treatment satisfaction with mandibular implant overdentures and conventional dentures: a randomized clinical trial in a senior population. Int J Prosthodont 2003; 16 : 390-396.

9. Thomason JM, Feine J, Exley C, Moynihan P, Muller F, Naert I, Ellis JS, Barclay C, Butterworth C, Scott B, Lynch C, Stewardson D, Smith P, Welfare R, Hyde P, McAndrew R, Fenlon M, Barclay S, Barker D. Mandibular two implant-supported overdentures as the first choice standard of care for edentulous patients--the York Consensus Statement. Br Dent J 2009; 207: 185-186.

10. Pae A, Kim JW, Kwon KR. Immediate loading of two implants supporting a magnet attachment-retained overdenture: one-year clinical study. Implant Dent 2010; 19: 428-436.

11. Heckmann SM, Winter W, Meyer M, Weber HP, Wichmann MG. Overdenture attachment selection and the loading of implant and denture-bearing area. Part 2: A methodical study using five types of attachment. Clin Oral Implants Res 2001; 12: 640-647.

12. Naert I, Gizani S, Vuylsteke M, Van Steenberghe D. A 5 -year prospective randomized clinical trial on the influence of splinted and unsplinted oral implants retaining a mandibular overdenture: prosthetic aspects and patient satisfaction. J Oral Rehabil 1999; 26: 195-202.

13. Spiekermann H. Implantology. In: Rateitschak, K.H. \& Wolf, H.F., eds. Color Atlas of Dental Medicine. New York: Thieme Medical Publishers. 1995: 164.

14. Heckmann SM, Winter W, Meyer M, Weber HP, Wichmann MG. Overdenture attachment selection and the loading of implant and denture-bearing area. Part 1: In vivo verification of stereolithographic model. Clin Oral Implants Res 2001; 12: 617-623.

15. Heckmann SM, Schrott A, Graef F, Wichmann MG, Weber HP. Mandibular two-implant telescopic overdentures. Clin Oral Implants Res 2004; 15: 560-569.

16. Besimo CH, Graber G, Fluhler M. Retention force changes in implant-supported titanium telescope crowns over longterm use in vitro. J Oral Rehabil 1996; 23: 372-378.

17. Chen IC, Brudvik JS, Mancl LA, Rubenstein JE, Chitswe K, Raigrodski AJ. Freedom of rotation of selected overdenture attachments: an in vitro study. J Prosthet Dent 2011; 106: 78-86.

18. Caruso G, Cattaneo A. Removable prosthesis supported by implants according to the Cagliari modified conometry technique: case report. Int J Periodontics Restorative Dent 2007; 27: 259-265.

19. Shafie HR. Clinical and Laboratory Manual of Implant Overdentures. Ames, Iowa, Blackwell Munksgaard, Asia Pty. Ltd 2007: 31-36.

20. Hoffmann O, Beaumont C, Tatakis DN, Zafiropoulos GG. Telescopic crowns as attachments for implant supported restorations: a case series. J Oral Implantol 2006; 32: 291-299.

21. Zafiropoulos GG, Hoffmann O. Five-year study of implant placement in regenerated bone and rehabilitation with telescopic crown retained dentures: a case report. J Oral Implantol 2009; 35: 303-309.

22. Beyli MS, von Fraunhofer JA. An analysis of causes of fracture of acrylic resin dentures. J Prosthet Dent 1981; 46: 238-241.

23. Gonda T, Maeda Y, Walton JN, MacEntee MI. Fracture incidence in mandibular overdentures retained by one or two implants. J Prosthet Dent 2010; 103: 178-181. 
24. Elsyad MA, El-Waseef FA, Al-Mahdy YF, Fouad MM. A comparison of mandibular denture base deformation with different impression techniques for implant overdentures. Clin Oral Implants Res 2013; 24 Suppl A100: 127-133.

25. 25. ELsyad MA, Errabti HM, Mustafa AZ. Mandibular Denture Base Deformation with Locator and Ball Attachments of Implant-Retained Overdentures. J Prosthodont 2016; 25: 656-664.

26. ELsyad MA, Fathe Mahanna F, Samir Khirallah A, Ali Habib A. Clinical denture base deformation with different attachments used to stabilize implant overdentures: A crossover study. Clin Oral Implants Res 2019.

27. el Ghazali S, Glantz PO, Strandman E, Randow K. On the clinical deformation of maxillary complete dentures. Influence of denture-base design and shape of denture-bearing tissue. Acta Odontol Scand 1989; 47: 69-76.

28. Im SM, Huh YH, Cho LR, Park CJ. Comparison of the fracture resistances of glass fiber mesh- and metal meshreinforced maxillary complete denture under dynamic fatigue loading. J Adv Prosthodont 2017; 9: 22-30.

29. Rached RN, de Souza EM, Dyer SR, Ferracane JL. Dynamic and static strength of an implant-supported overdenture model reinforced with metal and nonmetal strengtheners. J Prosthet Dent 2011; 106: 297-304.

30. Hada T, Suzuki T, Minakuchi S, Takahashi H. Reduction in maxillary complete denture deformation using framework material made by computer-aided design and manufacturing systems. J Mech Behav Biomed Mater 2019; 103: 103514

31. Zoidis P. The all-on-4 modified polyetheretherketone treatment approach: A clinical report. J Prosthet Dent 2018; 119: 516-521.

32. Conserva E, Menini M, Tealdo T, Bevilacqua M, Ravera G, Pera F, Pera P. The use of a masticatory robot to analyze the shock absorption capacity of different restorative materials for prosthetic implants: a preliminary report. Int J Prosthodont 2009; 22: 53-55.

33. Rosentritt M, Schneider-Feyrer S, Behr M, Preis V. In Vitro Shock Absorption Tests on Implant-Supported Crowns: Influence of Crown Materials and Luting Agents. Int J Oral Maxillofac Implants 2018; 33: 116-122.

34. Ohkawa S, Okane H, Nagasawa T, Tsuru H. Changes in retention of various telescope crown assemblies over longterm use. J Prosthet Dent 1990; 64: 153-158.

35. Weigl P, Hahn L, Lauer HC. Advanced biomaterials used for a new telescopic retainer for removable dentures:
Ceramic vs. Electroplated Gold Copings: Part I. In Vitro Tribology Effects. J Biomed Mater Res 2000; 53: 320-336.

36. Gonda T, Ikebe K, Dong J, Nokubi T. Effect of reinforcement on overdenture strain. J Dent Res 2007; 86: 667-671.

37. Akca K, Cehreli MC, Iplikcioglu H. A comparison of three-dimensional finite element stress analysis with in vitro strain gauge measurements on dental implants. Int $\mathrm{J}$ Prosthodont 2002; 15: 115-121.

38. Glantz PO, Nilner K. Biomechanical aspects on overdenture treatment. J Dent 1997; 25 Suppl 1: S21-24.

39. Obeid AA, Stafford GD, Bates JF. Clinical studies of strain behaviour of complete dentures. J Biomed Eng 1982; 4: 49-54.

40. Elsyad MA, Hegazy SA, Hammouda NI, Al-Tonbary GY, Habib AA. Chewing efficiency and electromyographic activity of masseter muscle with three designs of implantsupported mandibular overdentures. A cross-over study. Clin Oral Implants Res 2014; 25: 742-748.

41. ELsyad MA, Ibrahim AE, Nawar NHH, Belal TM. Electromyographic Connectivity of Masseter Muscle with Different Retentive Attachments for Implant Overdentures in Patients with Atrophied Mandibular Ridges: A Crossover Study. Int J Oral Maxillofac Implants 2019; 34: 1213-1222.

42. Stafford GD, Glantz PO. Intraoral strain gauge measurements on complete dentures: a methodological study. J Dent 1991; 19: 80-84

43. Dong J, Ikebe K, Gonda T, Nokubi T. Influence of abutment height on strain in a mandibular overdenture. J Oral Rehabil 2006; 33: 594-599.

44. Duncan JP, Freilich MA, Latvis CJ. Fiber-reinforced composite framework for implant-supported overdentures. J Prosthet Dent 2000; 84: 200-204.

45. Rodrigues AH. Metal reinforcement for implant-supported mandibular overdentures. J Prosthet Dent 2000; 83: 511-513.

46. Gibreel MF, Khalifa A, Said MM, Mahanna F, El-Amier N, Narhi TO, Perea-Lowery L, Vallittu PK. Biomechanical aspects of reinforced implant overdentures: A systematic review. J Mech Behav Biomed Mater 2019; 91: 202-211.

47. Takahashi T, Gonda T, Maeda Y. Can Reinforcement of Maxillary Implant Overdentures Decrease Stress on Underlying Implants? Int J Oral Maxillofac Implants 2017; 32: 63-69.

48. Takahashi T, Gonda T, Maeda Y. Influence of reinforcement on strains within maxillary implant overdentures. Int J Oral Maxillofac Implants 2015; 30: 1327-1332. 